\title{
The genetic structure of a tribal population, the Yanomama Indians
}

\author{
III. Seven serum protein systems*
}

\author{
By L. R. WEITKAMP, † T. ARENDS,§ M. L. GALLANGO,§ J. V. NEEL, $\dagger$ \\ J. SCHULTZ† AND D. C. SHREFFLER $\dagger$
}

The Yanomama Indians are a tribe of slash-and-burn cultivators who live deep in the tropical forests of southern Venezuela and northern Brazil. As a part of a larger study of microdifferentiation and gene flow we report the results of genetic typing of the haptoglobin $(\mathrm{Hp})$, transferrin (Tf), Group Specific Component (Gc), albumin (Alb), ceruloplasmin (Cp) and two beta lipoprotein $(\mathrm{Ag}$ and $\mathrm{Lp}$ ) systems in Yanomama Indians from 37 villages, each with 31 to 176 sampled individuals. The findings in several villages in which fewer than 30 individuals were sampled have been grouped together in a 'miscellaneous' category. The total number of persons typed for each system ranges between 359 (Ag system) and 2503 (Gc system). A report listing preliminary gene frequencies for the first ten of these villages has been previously prepared (Arends et al. 1967). The location of the villages and a description of the dates and techniques of blood collection and transport are given in Gershowitz et al. (1972) and Ward (1972).

\section{METHODS}

Typing for the seven serum protein systems was performed at the University of Michigan and at the Instituto Venezolano de Investigaciones Cientificas (IVIC). For some systems in some villages the types were independently determined at both IVIC and the University of Michigan (see below). Discrepancies in the findings in the two laboratories were reconciled by repeat typings in one or both laboratories.

In Michigan, for all but the first ten villages (03 KP through $11 \mathrm{HI})$ haptoglobin, transferrin, Group Specific Component, and albumin were typed using vertical starch-gel electrophoresis (lots 174, 350 and 682, Electro Starch Co., Madison, Wisconsin) according to the modifications of the techniques of Smithies (1959) and the buffer of Gahne (1963) as described by Bowman \& Bearn (1965), except that gels were run for 16-18 hr. at approximately $25 \mathrm{~V} . / \mathrm{cm}$. (cf. Fig. 1). Amido Black $10 \mathrm{~B}$ was used for the protein stain ( $\mathrm{Tf}, \mathrm{Gc}$ and $\mathrm{Alb}$ ) and either o-dianisidine (Owen, Silberman \& Got, 1958) or benzidine-nitroprusside (Higashi \& Lubs, 1966) for specific haptoglobin staining. In villages $03 \mathrm{~A}$ through $03 \mathrm{~J}$ Ge typing was performed on $8 \times 10 \mathrm{~cm}$ glass slides, using the buffer system and electrophoretic conditions described by Hirschfeld (1959) and a rabbit antiserum prepared against partially purified Ge protein. Screening for variants of ceruloplasmin was carried out with starch-gel electrophoresis either as described by Shreffler et al. (1967), or by the technique described above for haptoglobin, transferrin, Ge and albumin, but utilizing o-dianisidine as the specific Cp stain (Shreffler et al. 1967). Both methods give very comparable

* These investigations were funded in part by U.S. Atomic Energy Commission Grant AT(11-1)-1552.

$\uparrow$ Department of Human Genetics, University of Michigan Medical School, Ann Arbor, Michigan 48104.

$\ddagger$ Present address: Departments of Anatomy and Pediatrics, University of Rochester School of Medicine and Dentistry, Rochester, New York.

\$ Hematologia Experimental, Instituto Venezolano de Investigaciones Cientificas, Apartado 1827, Caracas, Venezuela. 
results. Albumin typing was also performed in one of the two vertical starch-gel systems used by Weitkamp et al. (1969): in villages $03 \mathrm{~A}$ through $08 \mathrm{~T}$ every other specimen was run in the acetate-EDTA, pH 5.0 system and the alternate sample in the tris-EDTA-borate, $\mathrm{pH} 6.9$ system; all specimens in $03 \mathrm{X}$ were typed in both systems, and all specimens in villages $08 \mathrm{O}$ through $011 \mathrm{HI}$ were typed only in the acetate-EDTA, pH 5.0 system.

Tests for the presence of the $\operatorname{Lp}(\mathrm{a})$ factor were performed on frozen plasma stored at $-70^{\circ} \mathrm{C}$. or on fresh plasma examined within $48 \mathrm{hr}$. of arrival of the specimens. Standard Ouchterlony double diffusion tests were carried out in $65 \mathrm{~mm}$. glass Petri dishes. The antiserum employed was a rabbit anti-Lp(a+); its preparation as well as the media and laboratory conditions have been previously described (Schultz, Schreffler \& Harvie, 1968).

At IVIC the procedures employed were essentially as described by Arends et al. (1970).

\section{RESULTS}

\section{The known polymorphisms}

The results of the classification for haptoglobin, Gc, transferrin, albumin, ceruloplasmin, Lp, and Ag are listed in Table 1. Transferrin, albumin, and ceruloplasmin are not polymorphic in this population. The gene frequencies for three of the four polymorphic systems ( $\mathrm{Hp}, \mathrm{Gc}$ and $\mathrm{Ag}$ ) are given in Table 2. Recent genetic studies in one of our laboratories (Schultz, 1970) have failed to confirm the autosomal dominant mode of inheritance previously proposed for the $L p(a)$ trait (Berg, 1963), at least for our test conditions. Since a more complex mode of inheritance is indicated, the calculation of $\mathrm{Lp}$ gene frequencies seems inappropriate and these are not included in Table 2. Of necessity, the $\mathrm{Ag}$ gene frequencies are calculated by taking the square roots of the respective recessive phenotype frequencies, assuming Hardy-Weinberg equilibrium. However, as we have emphasized in studies of other Indian villages (Neel et al. 1964), mating in these villages does not meet Hardy-Weinberg restrictions. In the past this has not introduced a serious problem into gene frequency calculations.

In order to evaluate again the errors likely to be introduced by the assumption of random mating, the $\mathrm{Hp}$ and $\mathrm{Gc}$ gene frequencies have been calculated by taking the square root of the Hp 1-1 and Ge 1-1 phenotype frequencies as well as by direct enumeration. With respect to the differences in the Gc system due to the two methods of calculation, the gene frequencies differed by more than 0.02 in only three villages and never by more than 0.04 . In 18 villages there is no discrepancy. The frequencies calculated by the assumption of Hardy-Weinberg equilibrium equally under-and over-estimated the true gene frequency determined by enumeration. Evaluation of the two methods of calculation with respect to haptoglobin is more complex. There was a considerable gradation in the intensity of haptoglobin staining among individuals; this plus the absence of the 2-1 M type in the Yanomama makes it probable that the 271 individuals without discernible haptoglobin (11.0\%) are instances of the acquired rather than genetic type of $\mathrm{Hp} \mathrm{O}$. These individuals have been excluded from both types of gene frequency calculations. There is risk in this, however, since it is technically easier to be certain about the presence of weakly staining haptoglobin bands in persons with the 2-1 or 2-2 phenotype rather than those with the 1-1 phenotype. In addition, the lesser sensitivity of the $o$-dianisidine staining procedure may have intensified a bias in those villages (earlier collections) in which this technique was used.

In fact, however, there is a minimally larger discrepancy between the two methods of calculation in the Hp system compared to the two methods in the Ge system. (In the Hp system no 


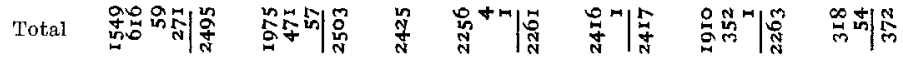

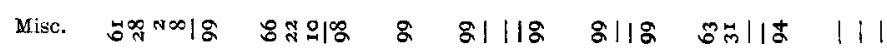

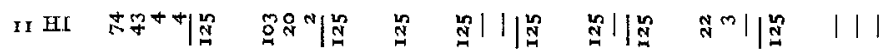

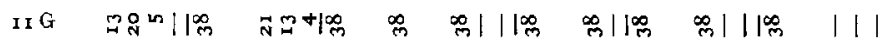

II

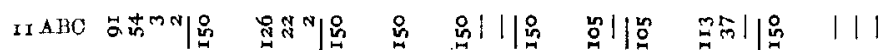

$08 \mathrm{XY}$ व이대

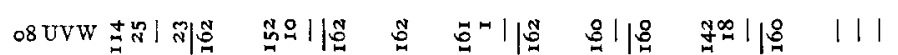

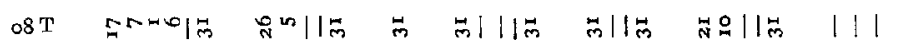

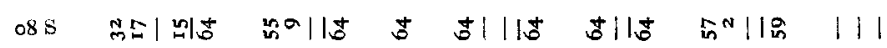

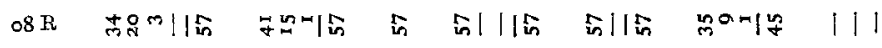

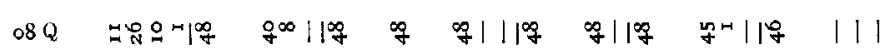

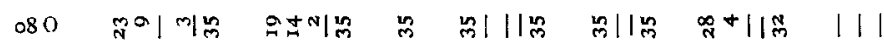

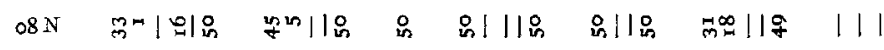

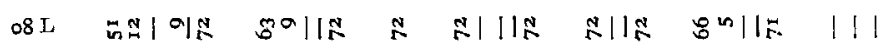

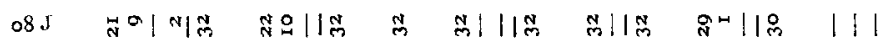

081 भुग

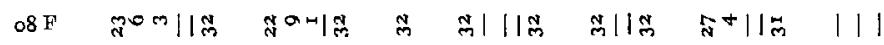

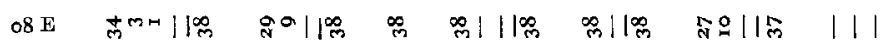

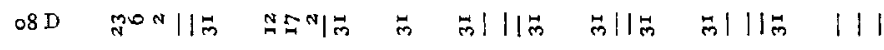

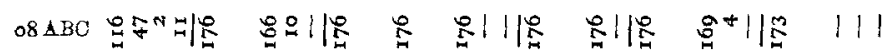

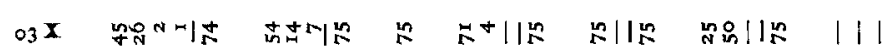

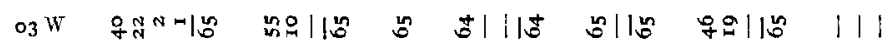

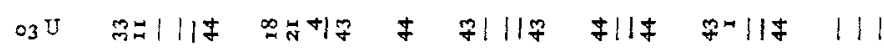

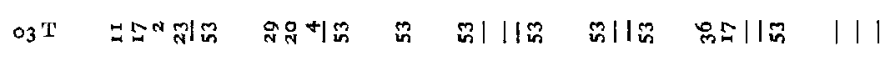

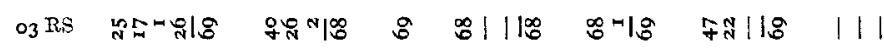

$03 \mathrm{Q}$ 尔

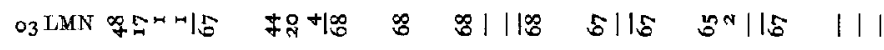

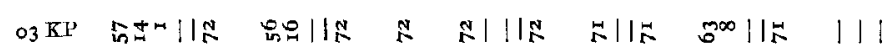

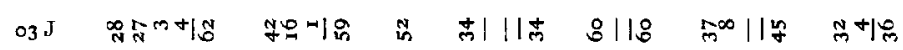

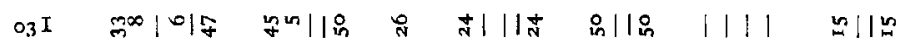

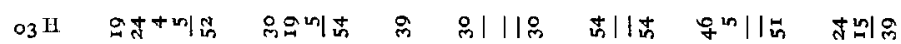

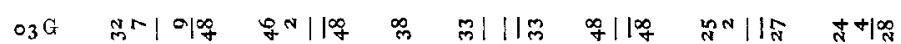

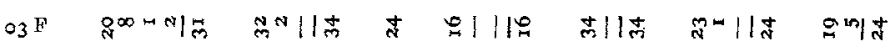

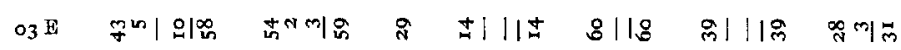

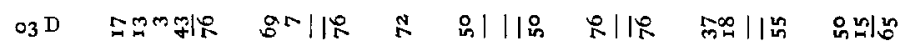

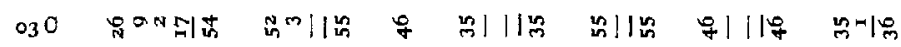

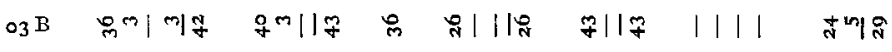

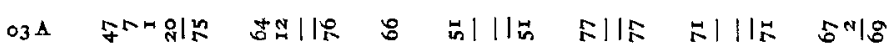

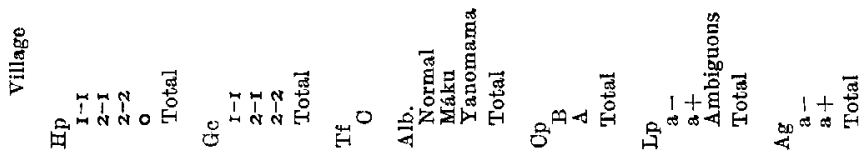

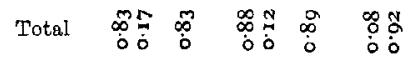

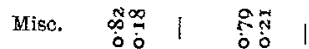

II HI

II

II I)

II ABO

IIABO

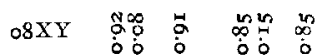

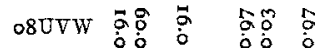

$\frac{\sqrt[5]{3}}{\sqrt[3]{3}}$

$08 \mathrm{~T} N \infty$ N

का

$08 \mathrm{~S}$ 造㠃

$08 \mathrm{R}$ คิ

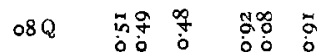

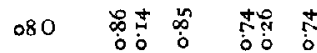

08 an 0 m 11

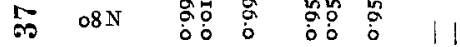

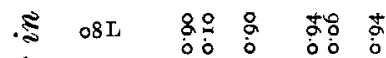

蛋

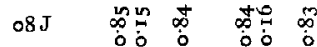

08I

o० 0 o 0 i 11

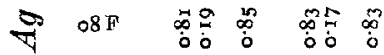

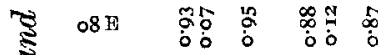

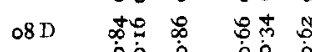

8

हो

O8ABO

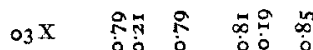

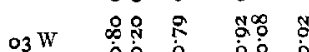

.ह

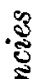

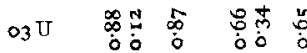

03T

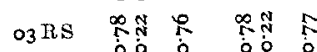

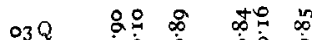

O3LMN

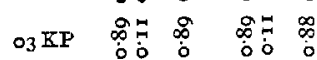

03 J

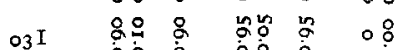

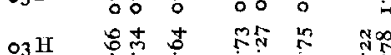

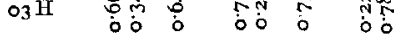

०3

03 $\mathrm{F}$ कृ की की

${ }_{03} \mathrm{E}$ iิ

का

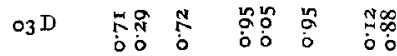

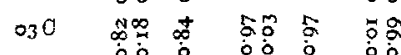

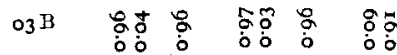

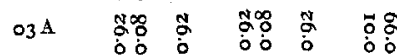

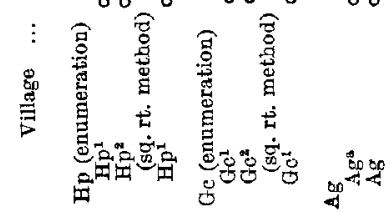


villages have a gene frequency difference greater than $0 \cdot 04$, five villages have a difference greater than 0.02 and 12 villages show no difference.) An increased discrepancy does not appear to occur in the villages with a higher frequency of $\mathrm{Hp} \mathrm{O}$ individuals. On the other hand, the gene frequency calculation on the assumption of Hardy-Weinberg equilibrium taken for each village individually slightly underestimates on average the true gene frequency for $\mathrm{Hp}^{1}$ obtained by enumeration, a situation consistent with the above-mentioned possibility of bias in Hp typing for technical reasons. In summary, it seems doubtful that the gene frequencies are significantly in error either in the haptoglobin system as a result of bias introduced by the large number of $\mathrm{Hp} \mathrm{O}$ individuals or in the $\mathrm{Ag}$ system as a result of non-random mating.

Village differences in gene frequency are, if taken at face value, large. Thus, the frequency of $\mathrm{Hp}^{1}$ varies from 0.51 to $0.98, \mathrm{Gc}^{1}$ from 0.66 to 0.98 and $\mathrm{Ag}^{\mathrm{a}}$ (ten villages only) from 0.01 to 0.12 . Further, the $\operatorname{Lp}(\mathrm{a})$ phenotype varies in frequency from 0.0 to 0.67 . The difficulties in applying standard statistical tests to the significance of such differences have been discussed elsewhere (Gershowitz et al. 1967). The distribution of Ge gene frequencies approximates the range found in seven Makiritare villages $\left(\mathrm{Gc}^{1}, 0 \cdot 64-0 \cdot 89\right.$; Arends et al. 1970), a tribe whose distribution overlaps in part that of the Yanomama (Chagnon et al. 1970). However, the gene frequencies for $\mathrm{Hp}^{1}$ in the Makiritare range from 0.24 to 0.65 (mean $=0.42$ ), a rather different distribution.

\section{'Private' variants}

Two types of rare albumin variants were found. Albumin Máku, a rapidly migrating variant found in four individuals in village $03 \mathrm{X}$, has been previously discussed (Weitkamp \& Chagnon, 1968; Chagnon et al. 1970). A different type of albumin variant, not previously reported, was found in one individual in village 08 UVW. Unfortunately, both of his parents were deceased, and he had no offspring. A comparison of the albumin pattern in this individual with the patterns obtained from an individual in the family studied by Fraser, Harris \& Robson (1959) and by Weitkamp et al. (1968), with albumin Makiritare (Arends et al. 1970), and with a dimer of normal albumin is shown in Fig. 1A. The bands in the position of the single arrow have been previously demonstrated to correspond with a dimer of albumin (Harris, 1961; Poulik, Zuelzer \& Meyer, 1961; Laurell \& Niléhn, 1966; Jamieson \& Ganguly, 1969). Laurell \& Niléhn (1966) first demonstrated a genetically determined broadening of the main albumin band on agarose gel electrophoresis in a Swedish family. On vertical starch-gel electrophoresis there was no increase in the breadth of the albumin band, but there was an additional minor band of albumin between the post-albumins and the 'fast $\alpha_{2}$-globulin zone'. This band disappeared after reduction with mercaptoethanol.

A variant albumin reported in an American Negro family (Jamison \& Rohde, 1966) has been extensively studied by Jamieson \& Ganguly (1969). This variant appeared to be produced as a result of dimerization involving non-covalent as well as disulphide bonds. They also demonstrated both a widening of the main albumin band and the presence of dimer on a single acrylamide gel. Using the vertical starch-gel electrophoretic systems referenced in this paper, no difference in mobility in either the monomer zone or the dimer zone could be detected among the albumin variants in the Welsh, Swedish and American Negro families reported by Fraser et al. (1959), Laurell \& Niléhn (1966) and Jamieson \& Rohde (1966), respectively (Weitkamp, unpublished). Turning again to Fig. IA, note the slightly more cathodal mobility of dimer albumin (single arrow) in an individual from the family described by Fraser et al. (1959) (position 5) compared 
to albumin dimer produced by denaturation of normal serum with acetone (position 7 ). The apparent dimer in albumin Yanomama (position 3 and 6) has a mobility slightly cathodal to that in position 5. In addition there is an elongation of the main albumin band cathodally (region of the double arrow). In albumin Makiritare (position 4) there is an even greater elongation of the main albumin zone and a still more cathodal position for the dimer variant. The pattern for albumin Makiritare is more clearly portrayed in an earlier photograph (Fig. 1B,
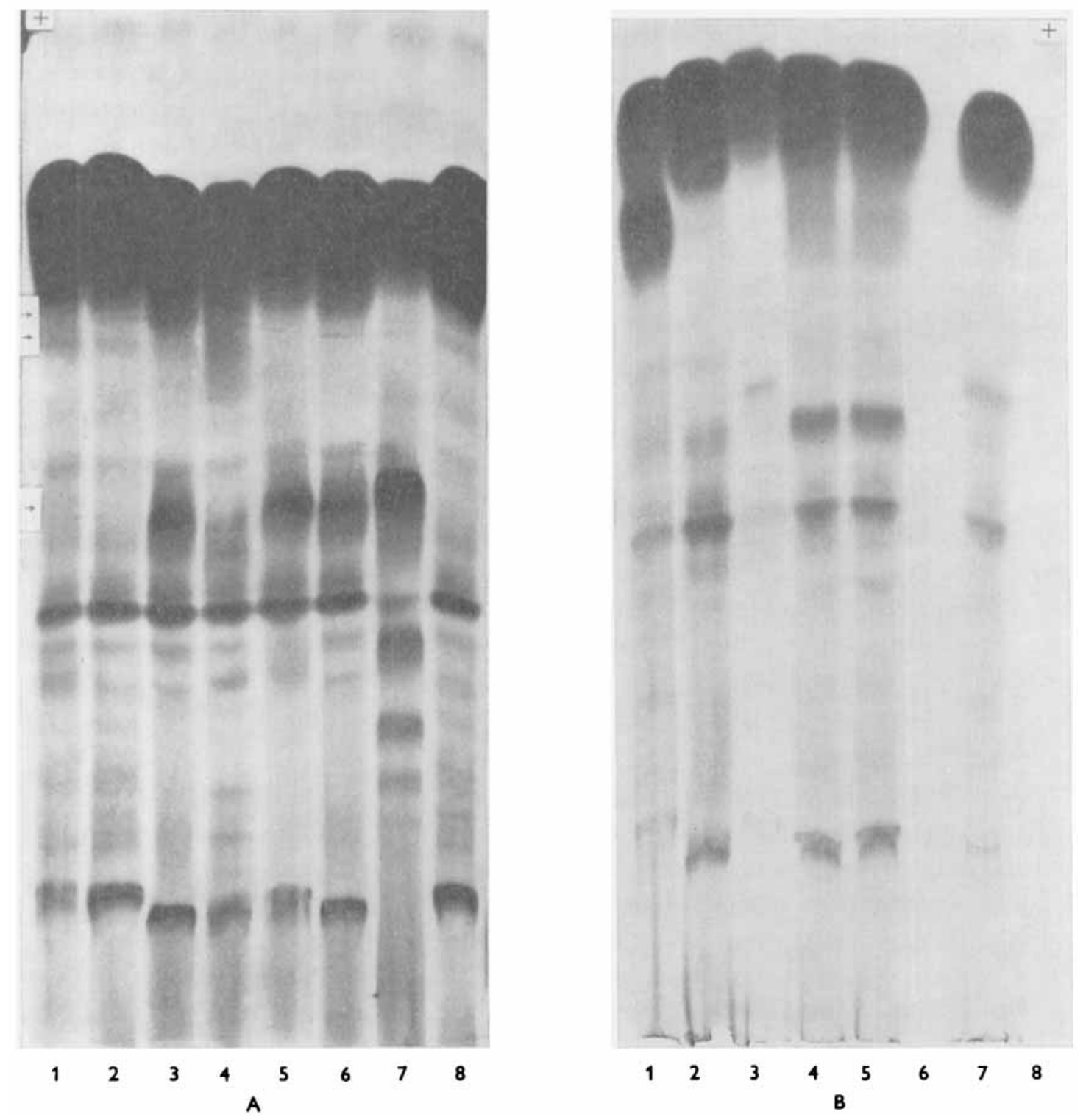

Fig. 1. Vertical starch-gel electrophoresis of human serum (see text for procedure). Origin is at the bottom, anode at the top. From left to right, Gel A: position 1, normal serum; 2, normal serum; 3, albumin Yanomama; 4, albumin Makiritare; 5, albumin of Fraser et al. (1959); 6, albumin Yanomama; 7, normal serum denatured by precipitation in acetone, resuspended in distilled water; 8 , normal serum. Gel B. position 1, family 10 (Weitkamp et al. 1969); 2, normal serum; 3, albumin of Fraser et al. (1959); 4 and 5, albumin Makiritare; 6, empty; 7, normal serum denatured by precipitation in acetone, resuspended in distilled water; 8 , empty. 
positions 4 and 5). An example from the class of most slowly migrating monomeric albumin variants is also shown in Fig. $1 \mathrm{~B}$ (position 1).

From the correlation of the increasing cathodal mobility of the dimer albumin band with the increasing cathodal elongation of the main albumin band (albumin Makiritare $>$ albumin Yanomama > Welsh, Swedish and American Negro dimer variants > normal albumin) it seems likely that the dimer variants are the result of monomeric albumin variants which have an increased tendency to dimerize. The relatively less intensely staining monomeric variant band in albumin Makiritare (gel 1B, position 4 and 5) compared to the monomeric variant band in family 10 (position 1 ) is consistent with such a conversion of monomeric variant to dimer. In addition, a similar value for the recombination fraction between alleles producing the dimer variant of Fraser et al. (Weitkamp et al. 1968), the Makiritare dimer variant (Arends et al. 1970), and a number of monomeric variants (Weitkamp et al. 1970) with alleles at the Ge locus is also consistent with the notion that all of these variants may be products of alleles at a single albumin locus.

The rapidly migrating ceruloplasmin variant found in apparently heterozygous condition with $\mathrm{CpB}$ in a woman in village $03 \mathrm{RS}$ has a mobility similar to $\mathrm{CpA}$. Unfortunately, the proposita's only tested relative was a sister who had the usual $\mathrm{CpB}$ phenotype. As in the case of albumin Yanomama the variant phenotype was repeatable and did not appear to be due to an artifact. Our inability to obtain repeat specimens in populations of this type, however, demands some diffidence in concluding, in the absence of confirmatory evidence of affected relatives, that the variant is genetically determined.

In a preliminary report (Arends et al. 1967) we mentioned the occurrence of two individuals with an apparently slowly migrating transferrin fraction (which, however, migrated more rapidly than $\mathrm{Tf} \mathrm{D}_{\mathrm{ch} \text { I }}$ ). One of these individuals had no identified relatives, but the other had normal parents and six apparently normal siblings. Repeat studies on stored samples reveal a broad transferrin band, but the division into two distinct components so important to the designation of a variant is lacking.

\section{DISCUSSION}

The present findings confirm and extend the earlier report of microdifferentiation among the Yanomama villages for certain polymorphisms, and the absence of polymorphism in the other systems known to be polymorphic in some Indian tribes (Arends et al. 1967). Similar findings have been reported for a tribe adjacent to the Yanomama, the Makiritare (Gershowitz et al. 1970 , et seq.). These are the first two relatively undisturbed tribes to be studied in such detail, so that any attempt at generalization would be premature, but one is perhaps permitted to speculate that the internal heterogeneity of tribal populations has been insufficiently appreciated in the past.

A discussion of the private variants is included in a subsequent paper (Weitkamp \& Neel, 1972). Here we note only that among the 11,785 electrophoretic determinations of proteins $(\mathrm{Hp}, \mathrm{Gc}, \mathrm{Tf}, \mathrm{Cp}$ and $\mathrm{Alb}$ ) there were three instances of different private variants (excluding ahaptoglobinaemia and the two possible transferrin variants). The genetic status of two of these, albumin Yanomama and the ceruloplasmin variant, is noted above. The third, albumin Máku, was found in a captured Máku Indian woman and three of her descendants. Her parents were not available for testing. 
The possible finding of another albumin variant (albumin Yanomama) indicates that perhaps five or six different albumin variants have been found among Indians of the American continent: three monomer variants (Weitkamp et al. 1969) as well as the dimer variants described here and in Arends et al. (1970) (Table 3). Thus far characterization has rested with electrophoretic differences, but undoubtedly the structural analysis of variants which is only now becoming possible (Jamieson \& Ganguly, 1969; Winter \& Rucknagel, 1971) will be necessary for definitive studies (especially when dealing with albumin dimer variants) and attempts to correlate structure with function.

Table 3. Albumin variants found among Indians of the American continent

Variant

Albumin dimer variants

Alb Warao

Alb Makiritare*

Alb Yanomama

Albumin structural variants

Alb Naskapi

Alb Máku

Alb Mexico
Population

Warao, Venezuela

Makiritare, Venezuela

Yanomama, Venezuela

Naskapi, U.S.A.

Máku, Brazil

Zapoteco, Mexico
Reference

Arends et al. 1969

Arends et al. 1970

This report

Melartin \& Blumberg, r 966

Weitkamp \& Chagnon, I 968

Melartin et al. I967

* Not certainly differont from Alb Warao.

It is noteworthy that of 2308 Yanomama Indians examined for the transferrin system, no variants different from the common transferrin, $C$, were found. The presence of transferrin $D_{c h i}$ in South American Indians (as well as other mongoloids) is not unusual (Arends, 1967) and there is even one tribe where the frequency of $\operatorname{Tf} \mathrm{D}_{\mathrm{chl}}$ approaches the more common $\operatorname{Tf} \mathrm{C}$ (Arends \& Gallango, 1964). If it develops that the presence of transferrin $\mathrm{D}_{\mathrm{chl}}$, although in low frequency, characterizes most Indian tribes, suggesting it may have been present from an early stage in Indian prehistory, this would constitute a case of loss of genetic variability in the Yanomama, of a type to be discussed in the following paper (Weitkamp \& Neel, 1972).

The haptoglobin system presents two important characteristics in this population. Firstly, 271 individuals were found without haptoglobin, the proportion reaching in some villages (03 $\mathrm{A}$, $03 \mathrm{C}, 03 \mathrm{D}, 03 \mathrm{RS}, 03 \mathrm{~T}) 27-56 \%$ of the entire population. These populations are situated for the most part on the banks of the Orinoco River and its tributaries, where malaria pressure may be assumed to be especially heavy, with resulting ahaptoglobinaemia because of the haemolytic process always accompanying this infection. On the other hand, the same Yanomama Indians living in Santa Maria del Erebato (villages 08 D, $08 \mathrm{E}$ and $08 \mathrm{~F}$ ), where ecologic conditions are not as favourable for the transmission of malaria, do not exhibit ahaptoglobinaemia. Secondly, it should be emphasized that there were no cases of Hp 2-1 (mod) in the 2476 individuals studied, confirming the absence of this gene in South American Indians (Arends, 1967).

\section{SUMMARY}

Data are presented on the results of typing Yanomama Indians in 37 villages, each with 31-176 sampled individuals, for seven serum protein systems ( $\mathrm{Hp}, \mathrm{Gc}, \mathrm{Tf}, \mathrm{Lp}, \mathrm{Cp}, \mathrm{Ag}$ and Alb). The findings confirm and extend substantially our earlier report of marked intervillage 
micro-differentiation for the polymorphic systems ( $\mathrm{Hp}, \mathrm{Gc}, \mathrm{Lp}$ and Ag). Among a total of 11,785 determinations in suitable systems ( $\mathrm{Hp}, \mathrm{Gc}, \mathrm{Tf}, \mathrm{Cp}$ and $\mathrm{Alb}$ ), there were three instances of different 'private' variants.

\section{REFERENCES}

ARends, T. (1967). Los grupos sérieos humanos determinables por métodos electroforéticos: su distribucíon en Sur América. Acta Cient. Venezolano 3, 162.

AREnds, T. \& Gallango, M. L. (1964). Transferrins in Venezuelan Indians: high frequency of a slow-moving variant. Science, N.Y. 143, 367.

Arends, T., Brewer, G., Chagnon, N., Gallango, M. L., Gershowitz, H., Layrisse, M., Neet, J., SHREFFLER, D., TASHIAN, R. \& WeITKAMP, L. (1967). Intratribal genetic differentiation among the Yanomama Indians of southern Venezuela. Proc. Natn. Acad. Sci. U.S.A. 57, 1252.

Arends, T., Gallango, M. L., Layrisse, M., Wrrbert, J. \& Heinen, H. D. (1969). Albumin Warao: new type of human alloalbuminemia. Blood 33, 414.

Arends, 'T., Weitkamp, L. R., Galdango, M. L., Need, J. V. \& Schultz, J. (1970). Gene frequencies and microdifferentiation among the Makiritare Indians. II. Seven serum protein systems. Am. J. Hum. Genet. 22,526 .

Berg, K. (1963). A new serum type system in man - the Lp system. Acta Path. Microbiol. Scand. 59, 369.

Bowman, B. H. \& BEARN, A. G. (1965). The presence of subunits in the inherited group specific component of human serum. Proc. Natn. Acad. Sci. U.S.A. 53, 722.

Chagnon, N. A., Neel, J. V., Weitkamp, L. R., Gershowitz, H. \& Ayres, M. (1970). The influence of cultural factors on the demography and pattern of gene flow from the Makiritare to the Yanomama Indians. Am. J. Phys. Anthrop. 32, 339.

Fraser, G. R., Harris, H. \& Robson, E. B. (1959). A new genetically determined plasma protein in man. Lancet $\mathrm{i}, 1023$.

$\mathrm{G}_{\mathrm{AHNE}}$ B. B. (1963). Inherited variations of the post-albumins of cattle serum. Hereditas $\mathbf{5 0}, 126$.

Gershowitz, H., Junqueira, P. C., Salzano, F. M. \& Neet, J. V. (1967). Further studies in the Xavante Indians. III. Blood groups and ABH-Le $e^{\mathrm{a}}$ secretor types in the Simões Lopes and São Marcos Xavantes. Am. J. Hum. Genet. 19, 502 .

Gershowitz, H., Layrisse, M., Layrisse, Z., Neei, J. V., Brewer, C., Chagnon, N. \& Ayres, M. (1970). Gene frequencies and mierodifferentiation among the Makiritare Indians. I. Eleven blood group systems and the ABH.Le secretor traits: A note on Rh gene frequency determinations. Am. J. Hum. Genet. 22, 515.

Gershowitz, H., Layrisse, M., Layrisse, Z., Neet, J., Chagnon, N. \& Ayres, M. (1972). The genetic structure of a tribal population, the Yanomama Indians. II. Eleven blood group systems and the ABH-Le secretor traits. Ann. Hum. Genet., Lond. 35, 261.

Harris, H. (1961). Inherited variations of human plasma proteins. Br. Med. Bull. 17, 217.

Hrgasm, G. I. \& LUBS, H. A., JR. (1966). Quantitative variations of haptoglobins in a Caucasian family. J. Med. Genet. 3, 281.

HIRsCHFeLd, J. (1959). Individual precipitation patterns of normal rabbit sera. Acta Path. Microbiol. Scand. 46, 220.

JAMIEson, G. A. \& Rohde, V. C. (1966). Genetically determined albumin dimer in a normal blood donor. Proc. 11 th Cong. Int. Soc. Blood Transfusion, Sydney. Bibl. Heemat., no. 29, part I, p. 415. Basel: S. Karger A. G.

Jamteson, G. A. \& Gavguly, P. (1969). Studies on a genetically determined albumin dimer. Biochem. Genet. 3, 403.

LaUReli, C. B. \& NilÉHn, J. E. (1966). A new type of inherited serum albumin anomaly. J. Clin. Invest. 45, 1935.

Medartin, L. \& Blumberg, B. S. (1966). Albumin Naskapi: a new variant of serum albumin. Science 153,1664 .

Melartix, L., Blumberg, B. S. \& Lisker, P. (1967). Albumin Mexico, a new variant of serum albumin. Nature 215, 1288.

Neet, J. V., Salzano, F. M., Junquetra, P. C., Keiter, F. \& Maybury-Lewis, D. (1964). Studies on the Xavante Indians of the Brazilian Mato Grosso. Am. J. Hum. Genet. 16, 52.

Owen, J. A., Silberman, H. J. \& Got, C. (1958). Detection of haemoglobin, haemoglobin-haptoglobin complexes and other substances with peroxidase activity after zone electrophoresis. Nature, Lonl. 182, 1373.

Poulik, M. D., Zuelzer, W. W. \& Meyer, R. (1961). Proteins in normal and nephrotic sera with filter paper electrophoretic mobility of albumin. J. Lab. Clin. Med. 57, 206.

SCHOLTZ, J. S. (1970). Immunochemical and genetic studies of the Lp system of human serum lipoproteins. Doctoral Dissertation, Ann Arbor: University of Michigan. 
Schultz, J. S., Shreffler, D. C. \& Harvie, N. R. (1968). Genetic and antigenic studies and partial purification of a human serum lipoprotein carrying the Lp antigenic determinant. Proc. Natn. Acad. Sci. U.S.A. 61, 963.

Shreffler, D. C., Brewer, G. J., Gali, J. C. \& Honfyman, M. S. (1967). Electrophoretic variation in human serum ceruloplasmin: A new genetic polymorphism. Biochem. Genet. 1, 101.

SMithIEs, O. (1959). An improved procedure for staroh-gel electrophoresis: Further variations in the serum proteins of normal individuals. Biochem. J. 71, 585 .

WARD, R. (1972). The genetic structure of a tribal population, the Yanomama Indians. V. A comparison of intervillago ethnic distances with ethnohistory. Ann. Hum. Genet. (in the Press).

Waickamp, L. R. \& Chagnon, N. A. (1968). Albumin Máku: a new variant of human serum albumin. Nature, Lond. 217, 759.

Weitkamp, L. R., Robson, E. B., Shreffrer, D. C. \& Corney, G. (1968). An unusual human serum albumin variant. Further data on genetic linkage between loci for human serum albumin and Group-Specific Component (Go). Am. J. Hum. Genet. 20, 392.

Weitkamp, L. R., Franglen, G., Rokala, D. A., Polesky, H. F., Simpson, N. E., Sunderman, F. W., Jr., Belt, H. E., SAave, J., Lisker, R. \& BoHls, S. W. (1969). An electrophoretic comparison of human serum albumin variants: Eight distinguishable types. Hum. Hered. 19, 159.

Weitkamp, L. R., Renwick, J.H., Berger, J., Shreffler, D. C., Drachmand, O., Wuhrmann, F., Brafind, M. \& Franglen, G. (1970). Additional data and summary for albumin-Ge linkage in man. Hum. Hered. $20,1$.

Weitkamp, L. R. \& NEEL, J. V. (1972). The genetic structure of a tribal population, the Yanomama Indians. IV. Eleven erythrocyte enzymes and summary of protein variants. Ann. Hum. Genet. 35 (in the press). Winter, W. P. \& Rucknaged, D. L. (197I). Amino acid sequence studies on an inherited human serum albumin variant. Fedn Proc. 30, 1295. 